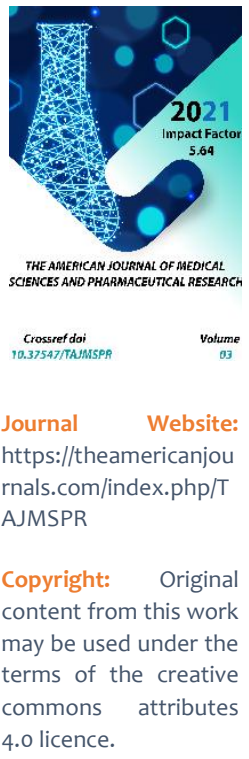

\title{
Improving The Treatment Of Paradontic Diseases With The Help Of Immunomodulating And Probiotic Drugs
}

Rizayev Jasur Alimjanovich

Samarkand State Medical Institute, Uzbekistan

Nazarova Nodira Sharipovna

Samarkand State Medical Institute, Uzbekistan

Nasreddinova Maxzuna Taxsinovna

Samarkand State Medical Institute, Uzbekistan

\section{ABSTRACT}

Parodontitis is one of the most common types of dental pathology. Many factors play a role in the emergence and development of this disease. Despite certain achievements in the study of the etiological and pathogenetic ome and in the development of parodontitis diagnostics and methods of treatment of Ome, its emergence and development have not yet been determined to the end.

The emergence and passage of parodontitis is accompanied by significant changes in the content of humoral factors in the oral fluid: IgA, which plays a leading role in the defense of the mucous membrane of the oral cavity, immunoglobulins of IgG classes and secretory immunoglobulins - slgA; albumin, whose concentration in the oral fluid increases as a result of increasing the permeability of the walls

\section{KEYWORDS}

Parodontitis, immunoglobulin IgA, IgG, local immuneitet, oral cavity homeostasis.

\section{INTRODUCTION}

According to modern concepts, cytokines are given the most important role in the management of immunogenesis processes. At the same time, cytokines of anti - inflammatory (leading-ONO - a) and anti-inflammatory (leading-IL-10) character control the processes of humoral and cellular immuneitet and the intensity of inflammation.

The oral cavity has a close anatomo physiological connection with various systems of the body. Pathogenetically, lesions of the mucous membrane of the oral cavity occur in 
violation of homeostasis, changes in the electrolyte and microelements balance, as well as in somatic diseases. With a deficiency or increase in macro - and microelements in the human body, resistance to unfavorable factors of the environment decreases, cases of immunodeficiency are formed, the activity of the antioxidant protective system is disrupted, diseases go into a chronic form, the risk of developing distributed diseases increases, the quality of life and the effectiveness of treatment decreases.

\section{PURPOSE OF THE STUDY}

Komplex treatment of parodontic diseases using a drug containing a combination of immunomodulator (timoptin) and antibiotic (paragel).

\section{RESEARCH MATERIAL AND METHODS}

To solve the identified task, we examined 40 patients with chronic parodontitis with mild, moderate, severe weight and 35 healthy people. In 2019-2021 the patients were in outpatient, examination and treatment at the Samarkand Regional Dental Clinic. The requested groups included 25 women and 15 men. Without a serious internal organ pathology, from 22 years to 65 years old.

We have developed special dental cards (Appendix 1). The survey of patients with chronic diffuse parodontitis began with a survey. To study the clinical and parodontal status of patients with chronic diffuse parodontitis, patients with the same degree of damage to parodontal tissues were included in the clinical groups $[3,6]$.

WHO classification was used in the diagnosis of Parodontal diseases (1983). The overall somatic status of the patients was assessed on the basis of general clinical studies, according to medical data of outpatient examinations conducted during clinical trials. The immuneitet status was determined by studying the leukocyte formula and individual immunograms of peripheral blood using conventional methods.

All people who were in our treatment, including clinical, immunological, radiological and laboratory research methods Komplex was examined. To all patients with chronic disseminated parodontitis, we developed and conducted a conservative treatment according to traditional methods, according to the indications, surgical measures, orthopedic and orthodontic treatment were carried out.

40 patients were treated witheksex. To assess the effectiveness of treatment, patients with chronic disseminated parodontitis are divided into two groups. The first main (I) group consisted of 20 people (Light Level - 3, medium - 13, Heavy - 4), the second comparison Group (II) - from 20 people (Light Level - 5, medium 12, Heavy - 3).

According to the results of our studies, chronic disseminated parodontitis is more common in women than men, from $68 \%$ to $32 \%$, in the group from 40 years to 65 years old, more often than in men.

\section{CONCLUSION AND DISCUSSION}

The results of the study of clinical indicators of patients with STP showed that, depending on the severity of the disease, the initial values of the indices in patients were different. The data are presented in Tables 5 and 6 . The values of these indices were used by us to control the 
efficacy of Komplex treatment in patients with mild, moderate, and severe STP using a test gel containing interferon and paragel.

As a result of the immunological examination, the appearance and passage of STP was found to be accompanied by serious changes in the composition of the studied humoral immuneitet factors in the oral cavity, which largely depends on the severity of the disease.

The leading humoral factors of local protection of mucous membranes - significant differences in some patients with chronic diffuse parodontitis due to the content in the oral cavity of immunoglobulins of Class A, are expressed in the presence of mucous membranes, including oral cavity, they ikkalasi. "zardobli" (IgA) and forms of secretion. (slgA).

Antibodies belonging to the latter will have the ability to maintain a protective effect on the surface of the mucous membranes due to the conjugation with the product of epithelial cells - "secretory attachment" (s).

Among patients with STP at all levels, a group of patients with a significantly reduced fluid content between $\lg A$ (30-50\%) and slgA (20$40 \%$ ) compared to the norm.

Deficiency of secretory immunoglobulins in the mucous membrane can be due to local or systemic causes. These, in particular, are genetically determined, primary and secondary due to the influence of various factors on the immuneitet system, systemic disorders of IgA synthesis, the ability of epithelial cells to synthesize the prefix and sequence "secretory" (s). other factors [4,6]..

Taking into account this, when analyzing the results of the study, we independently examined groups of patients with different variants of reducing the content of IgA in the oral cavity in serum and secretory forms). It should be noted that among patients with systemic diseases or significant changes in the intensity of Iga synthesis, the immunoitet status of patients was not determined in the study $[1,9]$.

Thus, in all patients with chronic diffuse parodontitis in the oral cavity, there are similar changes in the composition of humoral factors that characterize the formation of a local inflammatory process, the intensity of which largely corresponds to the severity of the lesion. However, at the same time, in a significant part of patients with the diagnosis of chronic diffuse parodontitis in the oral cavity, local violations of immunogenesis processes were detected. Basically, such violations are manifested by a decrease in the main humoral protective factors of the mucous membranes - slgA (up to 30 percent of all patients). At the same time, such a decrease can also be based on the suppression of IgA synthesis by the lymphocytes of the oral cavity and a violation of the synthesis of the secretory component (s) by epithelial cells for slgA.

Research on the production of therapeutic dental gel containing immunomodulator thymoptin and antibiotic - paragellum was conducted in the context of Pharmaceutical Technologies of the Belarusian State Medical University $[10,8]$.

At present, different types of interferon are known. From the blood of an industrial donor (Interferon alfa) produces leukocyte interferon, a lyophilizate (synonyms: Intereron - alfa, Beta - interferon, Interlok) for the preparation of a solution for $1000 \mathrm{ME}$ intranasal 
transmission, which has the ability to stimulate the phagocytic activity of macrophages, as well as cytostatic activity - T cells and "natural killer cells", which have an anti-viral effect, which leads to a state of resistance to infections in the cells and modulates the action of the immune systemitet.

Cells infected by them. With individual therapeutic use, the drug has proven itself as an immunomodulator in the treatment of chronic periodontitis $[11,5]$.

The known drug, paragelum (paragelum) France, Merion Merrel SA, contains white - gray or white-yellowish color powder and auxiliary substances - kaltsium carbonate and kaolin, hard gelatinous capsules with milk white with a specific odor, soluble, it forms a homogeneous suspension of white-gray color.

Baktisubtil is an antibiotic drug containing apatogen microorganisms, which do not enter the normal human microflora and are not capable of colonizing the skin and mucous membranes (representatives of the "temporary microflora" of the body's borderline tissue, vegetation on them) for a limited time). These are non-pathogenic drugs (musmosbat sticks that form aerobic spore), including apatogen for humans and animals and the drug cereus. Their ability to synthesize low molecular weight antibiotics - active polyps against various pathogens and opportunistic microorganisms, including the main pathogens of associated purulent infections-was determined. In the treatment of chronic diffuse parodontitis patients, antibacterial drugs based on the drug can be considered not only as a means of combating dysbiosis, but also as an additional etiotropic therapy, since they have antagonistic properties against opportunistic bacteria.

In addition to these properties, which provide a positive therapeutic effect of antibiotics from among Bacillus, it was found that these drugs have a modulating effect on the immune processes of macroorganism, which is associated with the production of a number of compounds with immunomodulatory properties by these microorganisms. Studies have shown that antibiotic drugs have an immunomodulatory effect: they restore the state of the immune system, in which pathology is impaired, increase the production of endothelium, increase the functional activity of macrophage cells and increase the phagocytic activity of blood leukocytes monocytes and neutrophils $[4,8]$.

The composition and technology of the Gel base meets the modern requirements of dental dosage forms.

To obtain the gel basis, as an object of study, we selected water solutions of methylcellulose, sodium carboxymethylcellulose, Lutrol - F 68, which were used in medical practice, at a concentration of $1 \%, 3 \%$.

When installing the experiment, an important factor of "convenience" was taken into account, the provision of which is possible with the use of the optimal selected concentration of high-molecular compounds, which ensures the maximum installation of drugs on the mucous membrane of the oral cavity.

The optimal concentration of high molecular weight compounds for gels was experimentally established. 
Structure of the Paragel:

Chlorgexidine glucanate

Metronidazole

Timoptin

Purified water

All components of the gel are approved for medical use. Paragel - gel for parodontic tissuethis is an antibiotic drug for the treatment and Prevention of infectious and inflammatory diseases of the oral cavity kuchaytiradiex, it has a long-lasting immunocorector effect kuchaytiradi, physiologic self-cleaning processes of the oral cavity kuchaytiradi. The effectiveness of the drug is due to the fact that it contains chlorgexidine, metrodinazole, timoptin in its composition.

Potentilla (goose paw) extracts-recommended for use in poor oral hygiene results with the help of traditional methods of treating parodontic inflammatory diseases kompleks (toothbrushes, profilactic toothpastes, elixirs, etc.).

Chlorgexidine [1.6-(paraxlorophenyl-guanide)hexane] - is a bactericidal antiseptic against many vegetative gram-negative and micronutrients. It only affects bacterial spores at high temperatures.

Pharmacological. the mechanism of action of potentilla (gazpanja) extract consists in the optimization of natural cleansing of the oral cavity by activating the physiologic processes of the oral cavity organs and accelerating immunocretion, activating the biocenosis of the parodontal ligaments. In the oral cavity, patogen inhibits the prerogative development of microflurane and the rapid formation of dental caries, their transformation into gum and milkosti stones. This feature of the Potentilla effect allows you to maintain the hygienic state of the oral cavity for a relatively long time. The bactericidal effect of chlorgexedine is due to a number of cations, which are negatively charged walls of bacterial cells and ecstramicrobial Kompleks. At low concentrations, chlorgexidine leads to a violation of the osmotic balance of bacterial cells and the cleavage of potassium and ftor from them, bacteriostatic effect. At a high concentration of chlorgexedine, the cytoplasmic composition of the bacterial cell precipitates, which eventually leads to the disappearance of bacteria.

Instructions for use.

Paragel is used to treat and prevent infectious diseases of the oral cavity, namely:

Acute gingivitis;

Acute wound necrotic gingivitis;

Chronic gingivitis and gingiva diseases;

Chronic hypertrophic gingivitis;

Chronic atrophic (dysvamative) gingivitis;

Chronic parodontitis;

Chronic aphthous (ulcerative) stomatitis;

Pislyaekstraktsian alveolitis;

Parodontitis in puberty;

Dental disease of infectious etiology. 
Methods of application and dosage: for dental use only.

After the teeth are thoroughly so, rinse with a solution of soda in the mouth and wipe parodont with a dry cotton swab. The resulting gel is packed in a $50 \mathrm{gr}$ flacon and covered with a flacon plastic. After opening, the shelf life of the drug is 2 years, and many times it is intended for application in okarmus.

Analysis of indicators using a new paragraph.in the chronic dynamics of the clinical course of treatment of parodontitis in general

When patients have a hangover, therapeutic and prophylactic measures should be taken locally, referring to the concomitant use of various methods and means that affect the periodontal disease and the general condition of the organism for bo general parodontitis. Taking into account the need to apply each approach, we have compiled a treatment plan and an individual with the appointment of adequate therapeutic tools and techniques in a certain sequence indispensable to the patient.

Local treatment began with the treatment of the oral cavity (removal of a toothpick or a national, replacement of poor-quality fillers, elimination of damaged occlusion, replacement of poorly performed prosthesis) with sanitation. An important method of treatment was to teach patients how to properly care for the oral cavity - rational cleaning and control of teeth, the use of dental floss with the display of special plaques and tables, recommendations for the purpose of toothpastes. Many times you have not eaten okarmus.

\section{CONCLUSION}

Thus, in a number of patients with chronic diffuse parodontitis in the oral cavity, local violations in the processes of immunogenesis, including a decrease in the main humoral factors (up to $30 \%$ of all patients) of the protection of the mucous membrane of the slgA, can be noted. The secretory to SlgA is the actual suppression and synthesis synthesis of component (s) disrupted.

With the local use of therapeutic gel with BC and fiber, the content of slgA in the oral cavity in the treatment of patients with chronic diffuse parodontitis increased more intensively than in conventional therapy, and in patients with initial slgA deficiency, eusification was significant; in clinical terms, the use of therapeutic gel provided a decrease in the treatment time from 19,8 to 8,5

\section{REFERENCES}

1. Гигиена полости рта при заболеваниях пародонта. СА Гаффаров, Ж.А. Ризаев, Ю.Х. Гайбуллаева - Методические рекомендации. Ташкент, 2010.

2. Rustem Hayaliev, Sabir Nurkhodjaev, Nodira Nazarova, Jasur Rizaev, Rustam Rahimberdiev, Tatyana Timokhina, Ivan Petrov. Interdisciplinary Approach of Biomedical Engineering in the Development of technical Devices for Medical research. Scopus. Journal of Biomimetics, Biomaterials and Biomedical and Biomedical Engineering ISSN: 22969845, Vol. 53, pp 85-92 2021 Trans Tech Publications Ltd, Switzerland.

3. J.A.Rizayev., Raximberdiev R.A., N.Sh.Nazarova. Ways to imporove The 
organization of dental services For chemical industry workers. The American journal of medical sciens and pharmaceutical research" № 2 (12) 2020.

4. J.A.Rizayev., Raximberdiev R.A., N.Sh.Nazarova. Ways to imporove The organization of dental services. Жамият ва инновациялар журнали.№ 12021.

5. Rizayev Jasur Alimdjanovich, Nazarova Nodira Sharipovna. Assessment of changes in the condition of periodontal tissues in workers exposed to exposure to epoxy resin. The American journal of medical sciences and pharmaceutical research 2019, №2 P 14-17.

6. Ризаев Ж.А., Назарова Н.Ш. Состояние местного иммунитета полости рта при хроническом генерализованном парадонтите. Вестник науки и образования 2020. № 14 (92).Часть 4. С 35-40.

7. Ризаев Ж.А., Назарова Н.Ш. Эффективность савокупного лечения болезней парадонта и слизистой оболочки работающих с вредными производственныыми факторами. Проблемы биологии и медицины.2020. №3 (119) . C 85-88.

8. Н.Ш. Назарова, Т.А. Бердиев. Эпоксид смолалар таъсирига учраган ишчиларда пародонтал тукималар холатининг узгаришини бахолаш. Жамият ва инновациялар. 2020, октябрь. C 566-570.

9. Ризаев Ж.А., Назарова Н.Ш., Бердиев. Т.А. Шиша толали тузилмаларни ишлаб чикариишда NBF гингивал гелининг самарадорлиги. Жамият ва инновациялар. 2020, октябрь С 678-682.

10. Н.Ш. Назарова, Т.А. Бердиев. Эпоксид смолалар таъсирига учраган ишчиларда пародонтал тукималар холатининг узгаришини бахолаш. Жамият ва инновациялар. 2020, октябрь. C 566-570.

11. Ризаев Ж.А., Назарова Н.Ш., Бердиев. Т.А. Шиша толали тузилмаларни ишлаб чикариишда NBF гингивал гелининг самарадорлиги. Жамият ва инновациялар. 2020, октябрь С 678-682.

12. Zhasur Alimdzhanovich Rizaev, Rahimberdiev Rustam Abdunosirovich, Nazarova Nodira Sharipovna. Ways to improve the organization of dental services for chemical industry workers. The American journal of medical sciences and pharmaceutical research. Volume 2 Issue 12, 2020, P 35-39. 